\title{
Penggunaan Metode Pembelajaran Peta Konsep (Mind Map) untuk Meningkatkan Hasil Belajar IPA Siswa Kelas VIII-B SMP Negeri 1 Ngimbang Semester I Tahun Pelajaran 2016-2017
}

\author{
WIWIK PUJIATI \\ Email :wiwikpujiati@gmail.com
}

\begin{abstract}
Abstrak:
Permasalahan yang ingin dikaji dalam penelitian ini adalah apakah penggunaan media peta konsep dapat meningkatkan hasil belajar IPA siswa kelas VIII-B SMP Negeri 1 Ngimbang semester I tahun pelajaran 2016-2017. Berdasarkan permasalahan tersebut, maka tujuan penelitian tindakan ini adalah untuk mengetahui apakah penggunaan media peta konsep dapat meningkatkan hasil belajar IPA siswa kelas VIII-B SMP Negeri 1 Ngimbang semester I tahun pelajaran 2016-2017. Sasaran penelitian ini adalah semua siswa VIII B SMP Negeri 1 Ngimbang semester I tahun pelajaran 2016- 2017 yang berjumlah 34 siswa. Penelitian ini menggunakan penelitian tindakan (action research) sebanyak tiga siklus. Setiap siklus terdiri dari empat tahap yaitu: rancangan, kegiatan dan pengamatan, refleksi, dan revisi. Penelitian ini menghasilkan simpulan bahwa penggunaan media peta konsep dapat meningkatkan hasil belajar IPA siswa kelas VIII-B SMP Negeri 1 Ngimbang semester I tahun pelajaran 2016-2017.
\end{abstract}

Kata kunci: Metode Peta Konsep (Mind Map)

\section{Pendahuluan}

Berdasarkan pengamatan di lapangan, rendahnya hasil belajar IPA banyak diakibatkan oleh kurangnya pengusaan konsep-konsep IPA secara fisik. Dengan kata lain siswa hanya menguasai konsep-konsep IPA hanya dari teori-teori yang dihafal. Dengan kondisi tersebut, maka pembelajaran IPA kurang bermakna bagi siswa. Berdasarkan permasalahan tersebut, perlu adanya pemikiran-pemikiran dan tindakan-tindakan yang harus dilalukan agar siswa dalam mempelajari konsep- 
konsep IPA tidak mengalami kesulitan, sehingga tujuan pembelajaran yang dibuat oleh guru mata pelajaran IPA dapat tercapai dengan baik.

Menurut Bruner (1966:10-11) ada tiga tingkatan utama modus belajar, yaitu pengalaman langsung (enactive), pengalaman pictorial/gambar (iconic), dan pengalaman abstrak (simbolic). Tingkatan pengalaman pemerolehan hasil belajar tersebut digambarkan sebagai suatu proses komunikasi. Materi yang ingin disampaikan pada siswa agar dapat menguasainya disebut sebagai pesan. Guru sebagai sumber pesan 
menuangkan pesan ke dalam simbolsimbol atau bagan-bagan tertentu (enacoding) dan siswa sebagai penerima menafsirkan simbol-simbol tersebut sehingga dipahami sebagai pesan (decoding).

Sebagai upaya meningkatkan mutu dan keberhasilan dalam proses pembelajaran, siswa sebaiknya diajak untuk memanfaatkan semua alat inderanya. Hendaknya guru berupaya untuk menampilkan rangsangan (stimulus) yang dapat diproses dengan berbagai indera. Levie \& Levie (1975) mengemukakan bahwa stimulus visual membuahkan hasil belajar yang lebih baik untuk tugas-tugas seperti mengingat, mengenali, mengingat kembali, dan menghubung-hubungkan fakta dan konsep. Di lain pihak, stimulus verbal memberi hasl belajar yang lebih baik apabila pembelajaran itu melibatkan ingatan yang berturut-turut (sekuensial).

Peran seorang guru dalam proses pembelajaran sangat menentukan tingkat keberhasilan dalam pencapaian tujuan pembelajaran. Sebagai mediator dan fasilitator, guru mempunyai tugas antara lain (1) menyediakan pengalaman belajar yang memungkinkan siswa ikut bertanggung jawab dalam membuat desain, proses dan penelitian, menyediakan atau memberikan kegiatankegiatan yang merangsang keingintahuan siswa, membantu siswa untuk mengekspresikan gagasan dan mengkomunikasikan idenya, memberi kesempatan dan pengalaman yang mendukung belajar siswa, (3) memonitor, mengevaluasi dan menunjukkan apakah pemikiran siswa terarah atau tidak. Dalam hal ini guru harus belajar mengerti cara berfikir siswa, sehingga dapat membantu siswa untuk mengkonstruksikan pengetahuannya

Pembelajaran mind map/Peta Konsep pada mata pelajaran IPA Terpadu di SMP merupakan bagian dari kegiatan belajar yang bertujuan untuk menumbuhkembangkan keterampilan siswa dalam menyerap informasi yang terdapat dalam materi IPA, sehingga tesnya difokuskan pada kemampuan memahami isi materi. Penggunaan model pembelajaran Peta Konsep atau mind map ini lebih didasarkan pada kemudahan untuk menggali informasi yang akan menarik minat siswa terutama dalam hal penyajian materi/bahan ajar yang lebih skematis, terperinci, dan lebih konkret dengan berbagai variasi gambar/tulisan yang menarik perhatian siswa yang belajar. Kemampuan memahami materi adalah kemampuan menangkap makna, baik yang tersurat mapun tersirat.

Peta konsep merupakan salah satu bentuk media pendidikan yang dapat menunjukkan konsep ilmu secara sistematis, dibangun dari inti permasalahan sampai dengan bagian pendukungyang mempunyai hubungan satu sama lain, sehingga membentuk sebuah pengetahuan yang dapat mempermudah proses pemahaman terhadap suatu pokok permasalahan (Pandley : 1994)

Berdasarkan uraian-uraian permasalahan sebagaimana tersebut di atas, maka masalah dalam penelitian ini dapat 
kami rumuskan sebagai berikut : "Apakah penggunaan metode pembelajaran peta konsep (Mind Map) dapat meningkatkan hasil belajar IPA siswa kelas VIII-B SMP Negeri 1 Ngimbang semester I tahun pelajaran 2016-2017?"

\section{Metode}

Menurut Mukhlis (2000: 5), Penelitian Tindakan Kelas (PTK) adalah suatu bentuk kajian yang bersifat sistematis reflektif oleh pelaku tindakan untuk memperbaiki kondisi pembelajaran yang dilakukan. Adapun tujuan utama dari PTK adalah untuk memperbaiki atau meningkatkan praktek pembelajaran secara berkesinambungan, sedangkan tujuan penyertaannya adalah menumbuhkan budaya meneliti di kalangan guru.

Penelitian ini dilaksanakan sebanyak 1 siklus. Sebelum masuk pada siklus I dilakukan tindakan pendahuluan yang berupa identifikasi permasalahan. Observasi dilakukan pada tiap siklus, dan melakukan kegiatan pembelajaran berdasarkan kompetensi dasar yang ingin dicapai. Proses pembelajaran pada masing-masing siklus dikenai perlakuan yang sama (langkahlangkah kegiatan yang sama), dimana perlakuan dalam setiap putaran (siklus) terdiri dari empat komponen pokok yaitu perencanaan, tindakan, observasi dan refleksi.

Langkah-langkah tersebut dapat digambarkan seperti berikut :

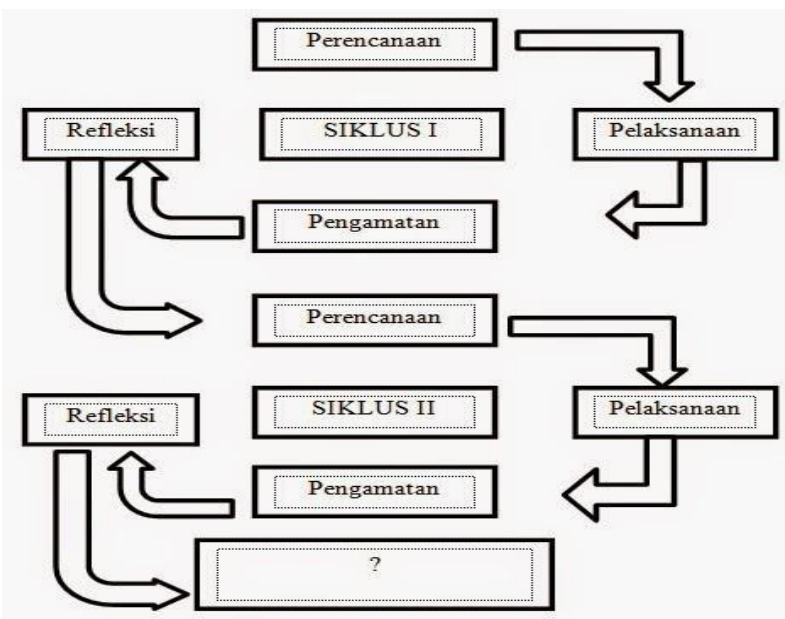

Gambar 1 : Prosedur Penelitian Tindakan

Kelas

Sasaran penelitian ini adalah semua siswa kelas VIII B SMPN 1 Ngimbang semester I tahun pelajaran 2016/2017 yang berjumlah 34 siswa. Instrumen yang digunakan dalam penelitian ini terdiri dari: Rencana Pelaksanaan Pembelajaran (RPP), model peta konsep, lembar observasi, lembar kerja Siswa, lembar penilaian dan alat-alat pendukung lainnya. Data-data yang diperlukan dalam penelitian ini diperoleh melalui kegiatan observasi terhadap aktivitas belajar siswa (data kualitatif) dan data hasil belajar siswa melalui pemberian tes formatif dalam setiap siklus (data kuantitatif).

Teknik analisis data yang digunakan dalam penelitian ini meliputi :

a. Teknik analisis deskriptif kualitatif, yaitu suatu metode penelitian yang bersifat menggambarkan kenyataan atau fakta sesuai dengan data yang diperoleh dengan tujuan untuk mengetahui tingkat partisipasi atau aktivitas siswa selama proses pembelajaran 
b. Teknik analisis data kuantitatif, yakni menganalisis tingkat keberhasilan atau persentase keberhasilan siswa setelah proses belajar mengajar dilakukan dengan cara memberikan evaluasi berupa soal tes tertulis atau tes formatif pada setiap akhir siklus. Teknik ini bertujuan untuk mengetahui prestasi belajar siswa yang tercermin pada tingkat ketuntasan belajar, baik secara individu maupun secara klasikal. Ketuntasan belajar untuk KTSP yang telah ditetapkan di SMPN 1 Ngimbang adalah sebagai berikut :

\section{Ketuntasan Individual}

Setiap siswa dikatakan tuntas jika mendapatkan nilai minimal sesuai dengan KKM, yakni 75. Untuk menghitung nilai yang diperoleh setiap siswa, digunakan rumus sebagai berikut :

Nilai $=$ LumlahSkor yang diperoleh $\times$ skala $(100)$ T11mlahskn+Maksimitm

\section{Ketuntasan Klasikal}

Sebuah kelas dikatakan tuntas belajar jika banyaknya siswa dalam kelas tersebut yang tuntas secara individual mencapai minimal 85\%. Untuk menghitung persentase ketuntasan belajar klasikal digunakan rumus sebagai berikut :

$$
\begin{aligned}
& T=\frac{\sum X}{\sum N} \times 100 \% \\
& \text { Dengan : } \\
& T \quad=\text { Persentase ketuntasan klasikal } \\
& \sum X \quad=\text { Jumlah siswa yang tuntas }
\end{aligned}
$$

\section{Hasil dan Pembahasan}

\section{Kondisi Aktivitas Belajar Siswa}

Pada siklus I, Siswa kurang bersemangat bekerja secara kelompok dalam pembalajaran, Siswa belum terbiasa dengan kondisi belajar menggunakan model pembelajaran dengan metode Peta Konsep, siswa malas menjawab pertanyaan dan saling menunggu teman atau kelompok lainnya, aktivitas interaksi dalam kelompok, menyamakan persepsi, saling menanyakan dalam kelompok masing kurang, sebagian besar siswa masih kurang disiplin dan percaya diri dalam menjawab soal. Secara umum kondisi aktivitas siswa dalam proses pembelajaran siklus I masih belum memuaskan.

Pada siklus II, Kegiatan pembelajaran semakin mengarah pada pembelajaran dengan metode Peta Konsep, siswa sudah terbiasa dengan kelompoknya dan bekerja sama dengan kelompok dalam memecahkan soal-soal dari guru, siswa menjadi lebih antusias mencari tahu kebenaran jawaban dengan peragaan langsung dan menyimak alasan yang tepat dari Guru, suasana pembelajaran sudah mulai terlihat aktif. Aspek yang masih belum terlihat adalah rasa percaya 
diri siswa mengemukakan pendapatnya.

Secara umum kondisi aktivitas siswa dalam proses pembelajaran siklus II lebih

baik dibanding siklus I. Akan tetapi masih ada aspek-aspek yang perlu

diperbaiki sehingga diperoleh kondisi aktivitas belajar siswa menjadi lebih baik.

Pada siklus III, sebagian besar siswa sudah semakin terbiasa dengan pembelajaran dengan metode Peta Konsep, siswa sudah terbiasa dengan kelompoknya dan bekerja sama dengan kelompok dalam memecahkan soal-soal dari guru, siswa lebih berani dan percaya diri mengemukakan pendapatnya dalam menyampaikan alasan-alasan dari jawaban yang diberikan mengenai peragaan yang disajikan, siswa menjadi lebih antusias mencari tahu kebenaran jawaban dengan peragaan langsung, suasana pembelajaran lebih "hidup" karena masing-masing kelompok secara bergantian ingin mempresentasikan hasil kerjanya dengan antusias. Dengan kondisi tersebut, maka Secara umum kondisi aktivitas siswa dalam proses pembelajaran siklus III sudah sangat baik dan memuaskan.

Untuk mengetahui secara jelas perubahan kondisi aktivitas belajar siswa sebagaimana tersebut di atas disajikan dalam bentuk grafik berikut :



Grafik 1 : Kondisi Aktivitas Belajar Siswa Pada

Pra Tindakan, Tindakan Siklus I dan Siklus II

\section{Hasil Belajar Siswa}

\section{Siklus I}

Adapun rekapitulasi data hasil belajar siswa pada siklus I adalah sebagai berikut :

\begin{tabular}{|l|c|}
\hline Nilai Rata-rata Kelas & 69 \\
\hline $\begin{array}{l}\text { Jumlah Siswa Tidak Tuntas } \\
\text { Belajar }\end{array}$ & 13 \\
\hline Jumlah Siswa Tuntas Belajar & 21 \\
\hline Persentase Ketuntasan Klasikal & $62 \%$ \\
\hline
\end{tabular}

Tabel 2 : Rekapitulasi Hasil Penilaian Tes

\section{formatif Siklus I}

Pencapaian nilai rata-rata tes formatif I sebesar 69, sedangkan jumlah siswa yang telah tuntas belajar sebanyak 21 siswa dari 34 siswa, dengan ketuntasan belajar klasikal sebesar 62\%. Hasil tersebut menunjukkan bahwa hasil belajar siswa pada siklus I masih belum optimal.

\section{Siklus II}

Adapun rekapitulasi data hasil belajar siswa pada siklus II adalah sebagai berikut : 


\begin{tabular}{|l|c|}
\hline Nilai Rata-rata Kelas & 75 \\
\hline $\begin{array}{l}\text { Jumlah Siswa Tidak Tuntas } \\
\text { Belajar }\end{array}$ & 9 \\
\hline Jumlah Siswa Tuntas Belajar & 25 \\
\hline Persentase Ketuntasan Klasikal & $74 \%$ \\
\hline
\end{tabular}

Tabel 3 : Rekapitulasi Hasil Penilaian Tes formatif Siklus II

Dari tabel di atas dapat diketahui bahwa nilai rata-rata siswa mengalami peningkatan, yakni dari 69 (siklus I) menjadi 75 pada siklus II. Selain itu juga dapat diketahui bahwa sebanyak 25 siswa dari 34 siswa (74\%) telah mencapai KKM atau telah tuntas belajar (pada siklus I terdapat 21 siswa atau 62\%). Dengan hasil tersebut maka dapat dikatakan bahwa hasil belajar siswa pada siklus II mengalami peningkatan jika dibanding pencapaian hasil belajar siswa pada siklus I. Peningkatan hasil belajar siswa pada siklus II tersebut tidak terlepas dari upaya guru memperbaiki proses pembelajaran berdasarkan hasil refleksi pembelajaran pada siklus I.

\section{Siklus III}

Adapun rekapitulasi data hasil belajar siswa pada siklus III adalah sebagai berikut :

\begin{tabular}{|l|c|}
\hline Nilai Rata-rata Kelas & 79 \\
\hline $\begin{array}{l}\text { Jumlah Siswa Tidak Tuntas } \\
\text { Belajar }\end{array}$ & 4 \\
\hline Jumlah Siswa Tuntas Belajar & 30 \\
\hline Persentase Ketuntasan Klasikal & $88 \%$ \\
\hline
\end{tabular}

Tabel 4 : Rekapitulasi Hasil Penilaian Tes

formatif Siklus III
Dari tabel di atas dapat diketahui bahwa nilai rata-rata siswa mengalami peningkatan, yakni dari 69 (siklus I), 75 (siklus II) menjadi 79 pada siklus III. Selain itu juga dapat diketahui bahwa persentase ketuntasan klasikal juga mengalami peningkatan, yakni sebanyak 30 siswa dari 34 siswa (88\%) telah mencapai KKM atau telah tuntas belajar (pada siklus I terdapat 21 siswa atau 62\%) dan pada siklus II terdapat 25 siswa atau 74\%). Peningkatan hasil belajar siswa pada siklus III tersebut tidak terlepas dari upaya guru memperbaiki proses pembelajaran berdasarkan hasil refleksi pembelajaran pada siklus I dan II. Dengan demikian dapat dikatakan bahwa secara umum tingkat keberhasilan atau pencapaian aspek-aspek dalam pembelajaran pada siklus III ini sudah optimal. Untuk mengetahui secara jelas perubahan data-data hasil belajar siswa selama 3 siklus sebagaimana tersebut di atas disajikan dalam bentuk tabel dan grafik berikut :

\begin{tabular}{|l|l|c|c|c|}
\hline No & $\begin{array}{c}\text { Hasil Belajar } \\
\text { Siswa }\end{array}$ & $\begin{array}{c}\text { Siklus } \\
\text { I }\end{array}$ & $\begin{array}{l}\text { Siklus } \\
\text { II }\end{array}$ & $\begin{array}{l}\text { Siklus } \\
\text { III }\end{array}$ \\
\hline 1. & Rata-rata Nilai & 69 & 75 & 79 \\
\hline 2. & $\begin{array}{l}\text { Persentase } \\
\text { Ketuntasan } \\
\text { Klasikal }\end{array}$ & $62 \%$ & $74 \%$ & $88 \%$ \\
\hline
\end{tabular}

Tabel 5 : Rekapitulasi Pencapaian Hasil Belajar Siswa Pada Siklus I, siklus II dan Siklus III 


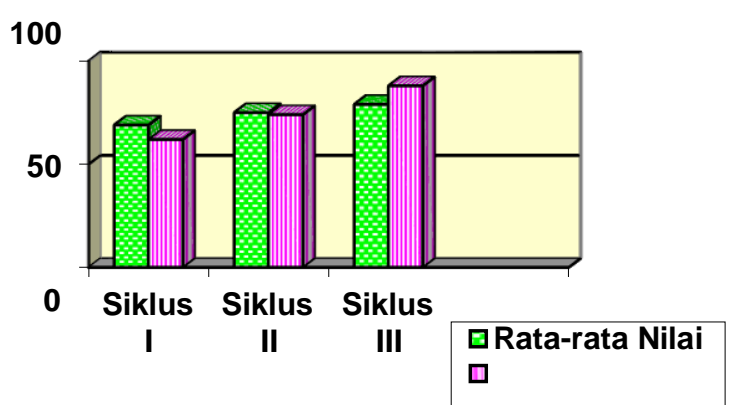

Grafik 2 : Tingkat Pencapaian KoltenkGeth rata dan Ketuntasan Klasikal Pada Siklus I, siklus II dan Siklus III

\section{Kesimpulan}

Dari hasil analisis seluruh data beserta pembahasannya, maka dapat diambil satu kesimpulan bahwa penggunaan metode pembelajaran peta konsep (Mind Map) dapat meningkatkan hasil belajar IPA siswa kelas VIII B SMPN 1 Ngimbang semester I tahun pelajaran 2016/2017.

\section{Daftar Pustaka}

Arsyad, Azhar. 1997. Media Pembelajaran. Jakarta: PT. RajaGrafindo Persada.

Corebima. 2003. Pembelajaran Kontekstual. Jakarta : Direktorat Pendidikan Lanjutan Pertama Ditjen

Dikdasmen Depdiknas.

Departemen Pendidikan dan Kebudayaan, 1994. Petunjuk Pelaksanaan Proses Belajar Mengajar, Jakarta. Balai Pustaka.

Djamarah, Syaiful Bahri. 2000. Strategi Belajar Mengajar. Jakarta: Rineksa Cipta.

Dahar, R.W. 1989. Teori-teori Belajar. Jakarta: Erlangga

Hamalik, Oemar. 1994. Media Pendidikan.

Bandung: Citra Aditya Bakti.

Arikunto, Suharsimi. 1998. Prosedur Penelitian Suatu Pendekatan Praktek. Jakarta: Rineksa Cipta

Soekamto, Toeti. 1997. Teori Belajar dan Model Pembelajaran. Jakarta: PAUPPAI, Universitas Terbuka.

Puspitasari. 2003. Strategi-strategi Belajar. Jakarta : Direktorat Pendidikan Lanjutan Pertama Ditjen Dikdasmen Depdiknas 